\title{
Structure Refinement of Five Layers Aurivillius Compound: $\mathrm{Ba}_{4} \mathrm{Bi}_{2} \mathrm{Nb}_{2} \mathrm{Ti}_{3} \mathrm{O}_{18}$
}

\author{
Ismunandar*, $^{*}$ \& Edi Mikrianto*,\# \\ *Department of Chemistry, FMIPA, Institut Teknologi Bandung \\ Jl. Ganesha 10 Bandung 40132
}

\begin{abstract}
The room temperature structures of the five layers Aurivillius phase $\mathrm{Ba}_{4} \mathrm{Bi}_{2} \mathrm{Nb}_{2} \mathrm{Ti}_{3} \mathrm{O}_{18}$ has been refined from X-ray powder diffraction data using the Rietveld method. The structures consist of $\left[\mathrm{Bi}_{2} \mathrm{O}_{2}\right]^{2+}$ layers interleaved with perovskite-like $\left[\mathrm{Ba}_{4} \mathrm{Nb}_{2} \mathrm{Ti}_{3} \mathrm{O}_{16}\right]^{2-}$ blocks. The oxides was found to be orthorhombic (SG B2cb); $a=5.5017(8), b=5.5031(8), c=50.363(3) \AA, \mathrm{R}_{\mathrm{p}}=$ $25.53 \mathrm{R}_{\mathrm{wp}}=35.54 \mathrm{R}_{\mathrm{exp}}=29.30 \mathrm{R}_{\mathrm{Bragg}}=9.92$. The structural features of the compound is found similar to that of other layered Aurivillius compounds. Using the available structural data the ferroelectric properties could be explained and strategies to find good ferroelectric materials could be inferred.
\end{abstract}

Keywords: Aurivillius phase; $\mathrm{Ba}_{4} \mathrm{Bi}_{2} \mathrm{Nb}_{2} \mathrm{Ti}_{3} \mathrm{O}_{18} ;$ Rietveld method; $X$-ray powder diffraction.

\section{Introduction}

Layered bismuth oxides commonly referred to as the Aurivillius phases have been known for more than 50 years (1). Recently there has been renewed interest in the ferroelectric properties of the Aurivillius phases due to their potential applications in nonvolatile computer memories (2). The Aurivillius phases, which have the general formula $\mathrm{Bi}_{2} \mathrm{~A}_{\mathrm{n}-1} \mathrm{~B}_{\mathrm{n}} \mathrm{O}_{3 \mathrm{n}+3}, \mathrm{n}=1,2,3, \ldots$ can be described as resulting from the regular stacking of $\left[\mathrm{Bi}_{2} \mathrm{O}_{2}\right]^{2+}$ slabs and perovskite-like $\left[\mathrm{A}_{n-1} \mathrm{~B}_{\mathrm{n}} \mathrm{O}_{3 \mathrm{n}+3}\right]^{2-}$ blocks. The integer, $\mathrm{n}$, describes the number of sheets of corner-sharing $\mathrm{BO}_{6}$ octahedra forming the $\mathrm{ABO}_{3}$-type perovskite blocks.

In comparison to the $n=2$ and 3 oxides, which have been extensively studied (3-5), very little is known about the higher order $n=4$ or 5 oxides. The synthesis and ferroelectric behavior of the $n=5$ oxides $A_{2} \mathrm{Bi}_{4} \mathrm{Ti}_{5} \mathrm{O}_{18}(A=\mathrm{Sr}, \mathrm{Ba}$ and $\mathrm{Pb}$ ) were first reported in 1962 (6-8). There were conflicting reports about the existence of single phase samples of $\mathrm{Ba}_{2} \mathrm{Bi}_{4} \mathrm{Ti}_{5} \mathrm{O}_{18}$; Subbarao reported that this is in fact a mixture of the four layer oxide $\mathrm{BaBi}_{4} \mathrm{Ti}_{4} \mathrm{O}_{15}$ and $\mathrm{BaTiO}_{3}$ while

\footnotetext{
$\Upsilon$ to whom correspondence should be addressed (ismu@chem.itb.ac.id)

* permanent address Program Studi Kimia FMIPA Unlam Jl. A Yani km 35,8 Banjarbaru Kalimantan Selatan
} 
Aurivillius claimed $\mathrm{Ba}_{2} \mathrm{Bi}_{4} \mathrm{Ti}_{5} \mathrm{O}_{18}$ could be obtained as a single phase. Recently Irie et.al. reported the preparation and ferroelectric properties of single crystals of $A_{2} \mathrm{Bi}_{4} \mathrm{Ti}_{5} \mathrm{O}_{18} \quad(A=\mathrm{Ba}$ and $\mathrm{Pb})(9)$. They indexed the patterns of both compounds in $B 2 a b$ with $a \approx b \approx 5 \AA$ and $c \approx 50 \AA$; no other structural parameters were reported.

In order to fill those gaps, recently we prepared a series of novel four and five layer Aurivillius compounds (10). We also carried out structural refinement of representative five layer compound (11). In the present paper, we report refinement of $\mathrm{Ba}_{4} \mathrm{Bi}_{2} \mathrm{Nb}_{2} \mathrm{Ti}_{3} \mathrm{O}_{18}$, one of the previously prepared oxides. The objective of the current reports is twofold. Firstly, it reports on the structure of an Aurivillius compound which has non Bi exclusively in the perovskite layers. Secondly, it illustrates that using laboratory source X-ray diffractometer sufficient important structural information could be obtained. The results of the determination could be used to explain the ferroelectric properties of the compounds. This eventually could be used in the search of optimal materials for ferroelectric memory.

\section{$2 \quad$ Experimental}

Polycrystalline samples of $\mathrm{Ba}_{4} \mathrm{Bi}_{2} \mathrm{Nb}_{2} \mathrm{Ti}_{3} \mathrm{O}_{18}$ was prepared by the solid state reaction of stoichiometric quantities of the appropriate alkaline $\mathrm{BaCO}_{3}, \mathrm{Bi}_{2} \mathrm{O}_{3}$, and $\mathrm{TiO}_{2}$ as described previously (10). Powder X-ray diffraction pattern was measured in MicroAnalysis machine using $\mathrm{Cu} \mathrm{K \alpha}$ radiation (1.54056 $\AA$ ) with graphite monochromator, in the range of $10.000 \mathrm{deg}$ to $90.000 \mathrm{deg}$ with 0.020 deg step size. Each step was counted for $6.00 \mathrm{sec}$. The Rietveld refinement (12) was carried out using Rietica (13). Sixty six parameters were refined in the final refinement, including cell parameter, positional parameter, peak shape, and thermal parameters. The $\mathrm{R}$ factors $\left(\mathrm{R}_{\mathrm{p}}\right)$, the weighted $\mathrm{R}$ factor $\left(\mathrm{R}_{\mathrm{wp}}\right)$, the Bragg $\mathrm{R}$ factor $\left(\mathrm{R}_{\text {Bragg }}\right)$ and $\mathrm{R}_{\text {exp }}$ are defined as follows: $\mathrm{R}_{\mathrm{p}}=\frac{\sum\left(\mathrm{y}_{\mathrm{i}}-\mathrm{y}_{\mathrm{ic}}\right)}{\sum \mathrm{y}_{\mathrm{io}}}$; $\mathrm{R}_{\mathrm{wp}}=\left(\frac{\sum \mathrm{w}_{\mathrm{i}}\left(\mathrm{y}_{\mathrm{i}}-\mathrm{y}_{\mathrm{ic}}\right)}{\sum \mathrm{w}_{\mathrm{i}} \mathrm{y}_{\mathrm{io}}^{2}}\right)^{1 / 2} ; \mathrm{R}_{\mathrm{Bragg}}=\frac{\left.\sum \mathrm{I}_{\mathrm{i}}-\mathrm{I}_{\mathrm{i}}\right)}{\sum \mathrm{I}_{\mathrm{io}}} ; \mathrm{R}_{\text {exp }}=\frac{\sum(\mathrm{N}-\mathrm{P})}{\sum \mathrm{Y}_{\mathrm{io}}}$, where $\mathrm{y}_{\mathrm{io}}$ and $\mathrm{y}_{\mathrm{ic}}$ are the observed and the calculated intensities, $\mathrm{w}_{\mathrm{i}}$ is the weighting factor $=1 / \mathrm{y}_{\mathrm{io}}, \mathrm{I}_{\mathrm{io}}$ and $\mathrm{I}_{\mathrm{ic}}$ are the observed and the calculated intensities of hkl reflection, $\mathrm{N}$ is the total number of $y_{i_{0}}$ data, $P$ is the number of parameters.

\section{$3 \quad$ Results and Discussion}

Structural parameter for $\mathrm{Sr}_{2} \mathrm{Bi}_{4} \mathrm{Ti}_{5} \mathrm{O}_{18}$ (11) was used as a starting model in the refinements. The refinement rapidly converged and the final R-factors and structural parameters (the atomic coordinates and isotropic displacement parameters) listed in Table 1. Examination of the Rietveld plots, Figure 1, and R 
values, suggested that a good fit has been obtained. The negative value obtained for $\mathrm{O}$ atoms thermal parameters is believed as a result of insensitivity of X-ray data to light atoms, despite that all $\mathrm{O}$ atoms were assumed to have the same thermal parameter. The same reason can be used to explain the relatively large estimated standard deviation (esd) for $\mathrm{O}$ atoms position.

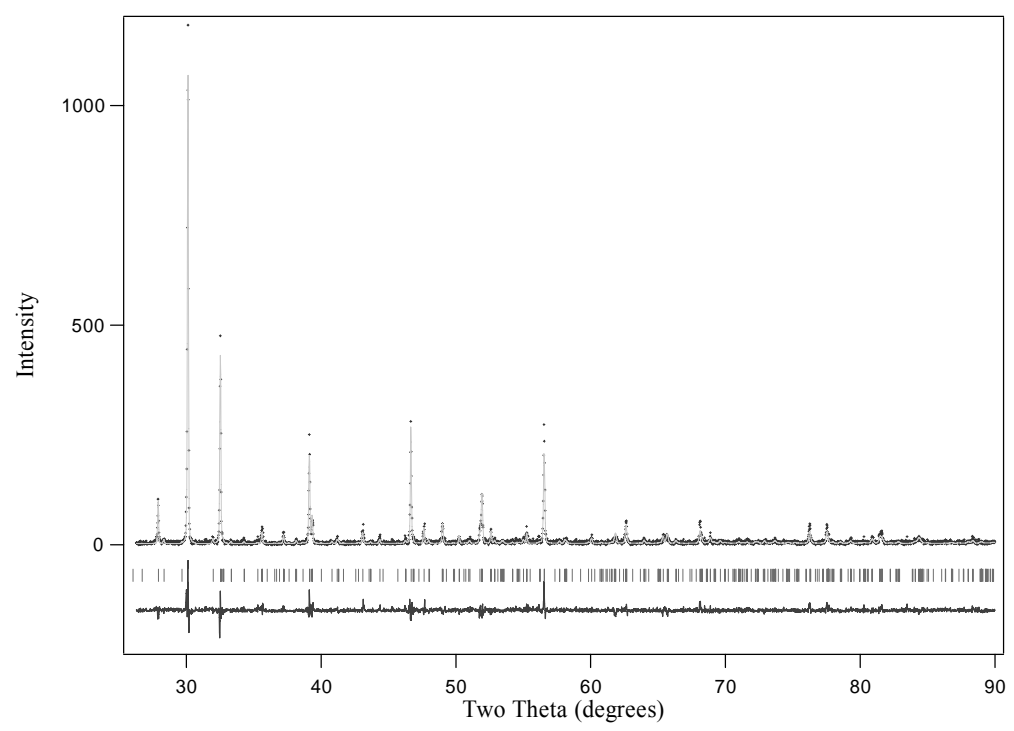

Figure 1 Rietveld refinement plot showing the observed $(\times)$, calculated (solid line) neutron diffraction profiles and their difference for $\mathrm{Ba}_{4} \mathrm{Bi}_{2} \mathrm{Nb}_{2} \mathrm{Ti}_{3} \mathrm{O}_{18}$ at room temperature. The tick marks show the positions of the allowed Bragg reflections in space group $B 2 c b$.

The observed cell parameters are larger than $\mathrm{Ba}_{2} \mathrm{Bi}_{4} \mathrm{Ti}_{5} \mathrm{O}_{18}$ (11) in agreement with the larger ionic radii of $\mathrm{Ba}^{2+}$ than $\mathrm{Bi}^{3+}$, as could be seen on the VIII coordinated $\mathrm{Bi}^{3+}$ and $\mathrm{Ba}^{2+}$ (14) (XII coordinated $\mathrm{Bi}^{3+}$ ionic radii is unavailable). The degree of the orthorhombic splitting, given by $\frac{2(a-b)}{(a+b)}$, obtained for this compound is smaller than those obtained for $A_{2} \mathrm{Bi}_{4} \mathrm{Ti}_{5} \mathrm{O}_{18}(A=\mathrm{Ca}, \mathrm{Sr}$ and $\mathrm{Pb})$, but larger than $\mathrm{BaBi}_{4} \mathrm{Ti}_{5} \mathrm{O}_{18}$. This can be explained using tolerance factor, $t$, defined as $t=\frac{\left(r_{A}+r_{O}\right)}{\sqrt{2}\left(r_{B}+r_{o}\right)}$ where $\mathrm{r}_{\mathrm{A}}$ is the radius of the 12-coordintate $\mathrm{A}^{2+}$ cation, $\mathrm{r}_{\mathrm{O}}$, the radius of the 4 coordinate oxygen anion and $r_{B}$ the radius of the sixcoordinate $\mathrm{Nb}^{5+} / \mathrm{Ti}^{4+}$ cation. As the size of the A-type cation increases through the series $\mathrm{Ca}(1.34)<\mathrm{Sr}(1.44) \approx \mathrm{Pb}(1.49)<\mathrm{Ba}(1.61 \AA)$ then $t$ increases, from less then unity in $\mathrm{CaBi}_{4} \mathrm{Ti}_{5} \mathrm{O}_{18}$ to greater than 1 in $\mathrm{BaBi}_{4} \mathrm{Ti}_{5} \mathrm{O}_{18}$. Further substitution of $\mathrm{Bi}^{3+}$ for $\mathrm{Ba}^{2+}$ will result in higher value. 


\begin{tabular}{lllll}
\hline Atom & $\mathrm{X}$ & $\mathrm{Y}$ & $\mathrm{z}$ & $\mathrm{B}\left(\AA^{2}\right)$ \\
\hline $\mathrm{Ba}(1)$ & 0.0000 & $0.984(5)$ & $0.0428(3)$ & $5.0(4)$ \\
$\mathrm{Bi}$ & $0.984(8)$ & $-0.007(3)$ & $0.2231(2)$ & $8.6(5)$ \\
$\mathrm{Ba}(2)$ & $-0.020(7)$ & $0.997(3)$ & $0.1326(2)$ & $1.7(3)$ \\
$\mathrm{Ti} / \mathrm{Nb}(1)$ & $-0.06(1)$ & 0.0 & 0.5000 & $6(1)$ \\
$\mathrm{Ti} / \mathrm{Nb}(2)$ & $0.00(1)$ & $1.000(6)$ & $0.3239(3)$ & $0.7(4)$ \\
$\mathrm{Ti} / \mathrm{Nb}(3)$ & $-0.06(2)$ & $0.98(2)$ & $0.414(1)$ & $22(2)$ \\
$\mathrm{O}(1)$ & $0.22(1)$ & $0.18(1)$ & $0.004(2)$ & $-3.3(5)$ \\
$\mathrm{O}(2)$ & $0.27(2)$ & $0.28(2)$ & $0.244(1)$ & $-3.3(5)$ \\
$\mathrm{O}(3)$ & $-0.04(2)$ & $1.02(2)$ & $0.292(1)$ & $-3.3(5)$ \\
$\mathrm{O}(4)$ & $0.92(2)$ & $1.04(2)$ & $0.378(1)$ & $-3.3(5)$ \\
$\mathrm{O}(5)$ & $0.96(2)$ & $1.07(1)$ & $0.458(1)$ & $-3.3(5)$ \\
$\mathrm{O}(6)$ & $0.02(2)$ & $0.14(2)$ & $0.037(2)$ & $-3.3(5)$ \\
$\mathrm{O}(7)$ & $0.25(1)$ & $0.16(1)$ & $0.922(2)$ & $-3.3(5)$ \\
$\mathrm{O}(8)$ & $0.20(2)$ & $0.20(2)$ & $0.837(2)$ & $-3.3(5)$ \\
$\mathrm{O}(9)$ & $0.21(2)$ & $0.18(1)$ & $0.160(2)$ & $-3.3(5)$ \\
\hline
\end{tabular}

Table 1 Positional and thermal parameters for $\mathrm{Ba}_{4} \mathrm{Bi}_{2} \mathrm{Nb}_{2} \mathrm{Ti}_{3} \mathrm{O}_{18}$, orthorhombic ( SG B2cb); $a=5.5017(8), b=5.5031(8), c=50.363(3), \mathrm{R}_{\mathrm{p}}=25.53 \mathrm{R}_{\mathrm{wp}}=35.54$ $\mathrm{R}_{\text {exp }}=29.30 \mathrm{R}_{\text {Bragg }}=9.92$.

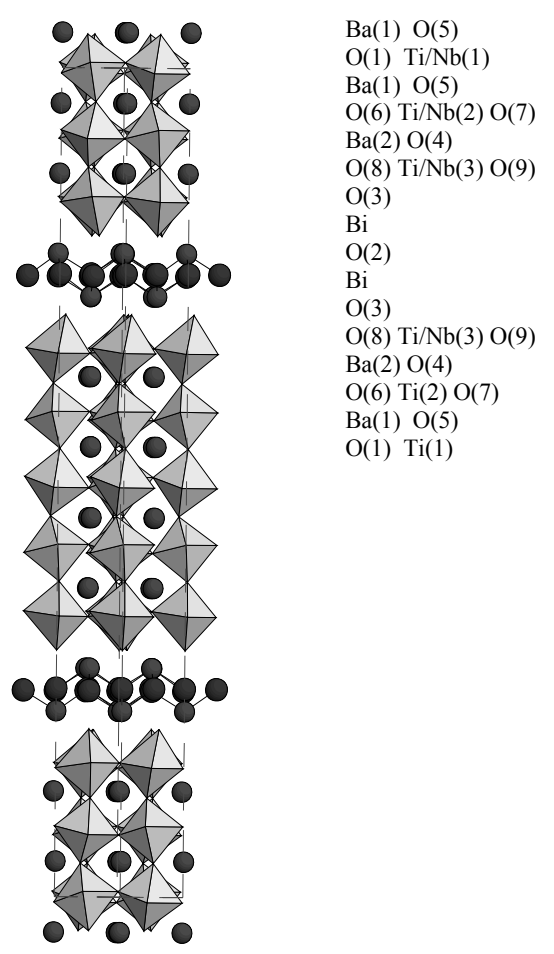

Figure 2 Structure of $\mathrm{Ba}_{4} \mathrm{Bi}_{2} \mathrm{Nb}_{2} \mathrm{Ti}_{3} \mathrm{O}_{18}$. 
Figures 2 shows the structures of $\mathrm{BaBi}_{4} \mathrm{Ti}_{5} \mathrm{O}_{18}$. Although high esd result in the relatively low accurate bond length and angles, the result also suggest that the local environments of the three crystallographically distinct $\mathrm{Ti}$ atoms are noticeably different. The outermost $\mathrm{MO}_{6}$ octahedra are highly distorted. Similar features are also observed in other Aurivillius oxides $(3-5,11)$. These features could be attributed to efforts to compensate the underbonding of $\mathrm{Ti}$ in the outermost octahedra.

The contribution of each constituent ion to the total spontaneous ferroelectric polarisation is calculated as: $\mathrm{P}_{\mathrm{S}}=\sum_{i}\left(\mathrm{~m}_{\mathrm{i}} \times \Delta \mathrm{y}_{\mathrm{i}} \times \mathrm{eQ}_{\mathrm{i}}\right) / \mathrm{V}$, where $\mathrm{m}_{\mathrm{i}}$ is the site multiplicity, $\Delta \mathrm{y}_{\mathrm{i}}$ is the atomic displacement along the $b$ axis from the corresponding position in the tetragonal structure, $\mathrm{Q}_{\mathrm{i}} \mathrm{e}$ is the ionic charge for the ith constituent ion, and $\mathrm{V}$ is the volume of the unit cell. Figure 3 compares the polarisation calculation results for $\mathrm{Ba}_{2} \mathrm{Bi}_{4} \mathrm{Ti}_{5} \mathrm{O}_{18}$ and $\mathrm{Ba}_{4} \mathrm{Bi}_{2} \mathrm{Nb}_{2} \mathrm{Ti}_{3} \mathrm{O}_{18}$. This clearly shows that the substitution of $\mathrm{Ba}$ for $\mathrm{Bi}$ in the perovskite enhances the polarisation. This is in contrast with the result of similar substitution in two layer Aurivillius, where the substitution results in reducing the total polarisations (15). Although it should be noted that considering the estimated standard deviation and the contribution of other ions, the total polarisations could be reduced. However, the precise oxygen atoms positions would be needed, i.e. neutron powder diffraction experiment is needed.

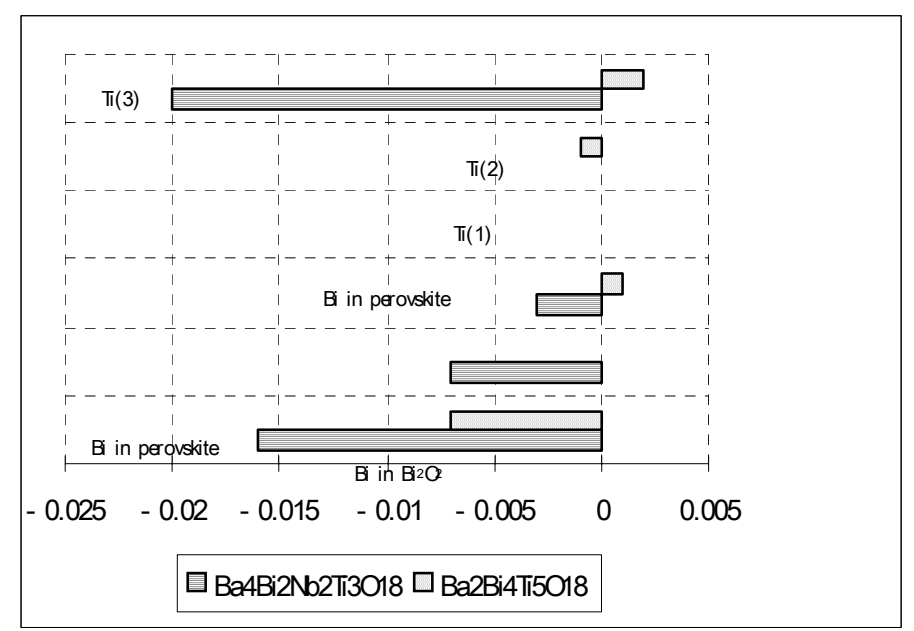

Figure 3 The polarisation contribution in $\mathrm{Ba}_{4} \mathrm{Bi}_{2} \mathrm{Nb}_{2} \mathrm{Ti}_{3} \mathrm{O}_{18}$ compared with those in $\mathrm{Ba}_{2} \mathrm{Bi}_{4} \mathrm{Ti}_{5} \mathrm{O}_{18}$.

In summary this experiment has shown that structure of new five layers Aurivillius compound $\mathrm{Ba}_{4} \mathrm{Bi}_{2} \mathrm{Nb}_{2} \mathrm{Ti}_{3} \mathrm{O}_{18}$ has determined. The non $\mathrm{Bi}$ cations 
which exclusively occupy the inner of perovskite layers result in enhancement of ferroelectricity. Further work to determine the precise position of the light atoms using powder neutron diffraction is being carried out and will be reported in due course.

\section{Acknowledgements}

Ismu thanks to HB X and TWAS for supporting the work.

\section{References}

1. Aurivillius, B., Ark. Kemi 1, 499 (1949).

2. de Araujo, C. A. P. et al, Nature (London) 374, 627 (1995).

3. Ismunandar, Hunter, B. A. and Kennedy, B. J., Solid State Ionics, 112(34), 281 (1998).

4. Macquart, R., et al, Integrated Ferroelectric, 2003.

5. Hervoches, C. H. and Lightfoot, P., J. Solid State Chem., 153, 66 (2000).

6. Subbarao, E. C., J. Am. Ceram. Soc. 45, 564 (1962).

7. Subbarao, E. C., J. Am. Ceram. Soc. 45, 166 (1962).

8. Aurivillius, B., Fang, P. H., Phys. Rev. 126, 893 (1962).

9. Irie, H., Miyayama, M. and Kudo, T., J. App. Phys, 90, 4089 (2001).

10. Edi Mikrianto and Ismunandar, JMS, 2003, submitted.

11. Ismunandar, et al, J. Neutron Res., 2004, in press.

12. Young, R. A. "The Rietveld Methods", OUP Inc., NY, 1993.

13. Howard, C. J. and Hunter, B. A., 1998 A Computer Program for Rietveld Analysis of X-Ray and Neutron Powder Diffraction Patterns (NSW, Australia: Lucas Heights Research Laboratories) 1-27.

14. Shanon, R. D., Acta Crystallogr., A32, 751, 1976.

15. Shimakawa, Y. et al, App. Phys. Lett., 74, 1904, 1999. 